\title{
Understanding the Society and Governance of Bangladesh through the Lens of Ibn Khaldun
}

\author{
Samiul Islam ${ }^{*}$, Amzad Hossain ${ }^{2}$ \\ ${ }^{1}$ Department of Sociology \& Anthropology, Green University of Bangladesh, Dhaka, Bangladesh \\ ${ }^{2}$ Department of Sociology, Pabna Edward College, National University, Govt. of Bangladesh, Pabna, Bangladesh \\ Email: *samiul511@gmail.com, amzad15december@gmail.com
}

How to cite this paper: Islam, S. and Hossain, A. (2017) Understanding the Society and Governance of Bangladesh through the Lens of Ibn Khaldun. Open Journal of Social Sciences, 5, 194-215. https://doi.org/10.4236/jss.2017.54018

Received: March 12, 2017

Accepted: April 25, 2017

Published: April 28, 2017

Copyright (C) 2017 by authors and Scientific Research Publishing Inc. This work is licensed under the Creative Commons Attribution International License (CC BY 4.0).

http://creativecommons.org/licenses/by/4.0/

Open Access

\begin{abstract}
This article attempts to ground the relevance and importance of 14th century's multifaceted social scientist Ibn Khaldun in the context of the overall social, cultural, economic and political journey of Bangladesh. The famous book of this eminent Muslim thinker the Mukaddimah is considered as the conceptual basis of this study. More precisely, from a sociological point of view, the article tries to examine Khaldun's concept of 'Asabyyah (solidarity), Umran (the nation) and Madaniyyah (civilization) in the context of Bangladesh. Doing so, a historical analysis of the society and culture of this delta will be portrayed first from Khaldun's framework of social interpretation. Then, the second part will focus on the continuous formation and reformation of Bangladesh as a state and as a unique society through its contemporary experiences at various social-cultural, economic and political contexts on the basis of both from local and global perspectives. The study gathers the nectar from the Muqadimmah, translation of the original text by Ibn Khaldun along with various journal or research papers by different scholars around the world. The study found that Khaldun's idea of 'Asabyyah is extensively applicable in explaining the historical, social and political process of Bangladesh. After discovering historical context, the study found that Khaldun can be considered one of the prime philosophers to address the future of the people of Bangladesh as a sustainable society and a proud nation through creating self-ego that will boost up its citizens in cooperating morally and intellectually from local to global.
\end{abstract}

\section{Keywords}

Mukaddimah, 'Asabyyah, Umran, Madaniyyah, Self-Ego

\section{Introduction}

Ibn Khaldun, was one of the most important Muslim historiographer, scholar 
and sociologist whose full name is Wali ad-Din Abu Zaid' abdar-Rahman b. Muhammad Ibn Khaldun. As Al-Azmeh [1] denotes, he was born in Tunis on May 27, 1332 and died in Cairo in 1406. His ancestors came to Seville in the eighth century and settles there. Then they immigrated to Ceuta before Tunis just before the Crusade in 1248. Black Death of 1347-1348 had carried away his parents and the situation was worsened for Ibn Khaldun. Despite of the fact that, he would get his position in politics as his ancestors done; his political carrier began under Ibn Tafraghin's Hafsid regime as katib al-alama. Being unhappy with his position, he followed his teacher and went to Fez where he stays in Abu Inan's court. When Fez become so unstable he emigrated to Granada where he did some missions for the ruler of Granada, Ibn al-Ahmar. Acieving a great influence in Granada, he was invited by Abu' Abd Allah to become his prime minister. In March 1365, he became Chamberlain of Bougie prince, Abu' Abd Allah who was killed by rebels 1365 . Then Ibn Khaldun left there and began to move around Maghreb, regulating tribal levies and relations. During his visit to Dawawida, one of these tribes' territories, he decided for retirement from royal affairs. There he lived under protection of Awlad'Arif tribe in Qal'at Ibn Salamah village. His writing of Kitab al-Ibar, a world history, comes across at that time period. He finished introduction, the Muqaddimah, in 1377 In 1373 Ibn Khaldun left Qal'at Ibn Salamah in 1373 and entered to service of Sultan of Tunis where he devoted himself to study and research only. In 1384, he appointed to Qamhiyah College in Cairo. In the same year he lost his whole family at a ship wreck. In 1387, he made a pilgrimage to Mecca, another pilgrimage to Jerusalem, Bethlelem, Hebron returning from Damascus in 1400. In March 1406 he died in Cairo and he was buried in the Sufi Cemetery outside Cairo [2].

Initially, this article tries to give a brief overview of Khaldhun's major workMuqaddimah and unpack the meanings of 'Asabiyyah which is the central phenomenon of this study. Then the discussion projects on contextualizing Khaldun's thoughts in understanding the history of Bangladesh. After that, it will move on to analyze regional polity of the globe. Followed by the global-regional context, the application of his thought is localized in exploring the ethnic boundaries of Bangladesh. Thereafter, it attempts to portray the historical journey of nationalism from global to local. Finally, pertaining Khaldunn's idea of civilization, the article reveals how a country like Bangladesh is moving forward to form its self-ego.

\section{Brief Discussion of the "The Introduction": Muqaddimah}

"Rational in its approach, analytical in its method, encyclopaedic in detail, it represents almost complete departure from traditional historiography, discarding conventional concepts and clichés a seeking, beyond the mere chronicle of events, an explanation of history." [3].

This is the basic explanation of translator of the Muqaddimah about the book. Here the Muqaddimah refers to translation of the original work of Ibn Khaldun 
by Franz Rosenthal, "Introduction", The Muqaddimah: An Introduction to History [4]. In the following part of the paper, some parts of Rosenthal's translation is analyzed to get a comprehensive examination of the 'Asabiyyah concept, which is translated by Rosenthal as "group feeling" in the whole translation. What we know as Muqaddimah (introduction or prolegomena) consists Preface and Book I of IbnKhaldun's universal history, Kitab al-'Ibar .

The Muqaddimah has a specific framework. It consists of the Introduction, Book One of the Kitab al-'Ibar. Book One of the Kitab al-'Ibar comprises of 6 Chapters and the concept of state, civilization, history, group feelings and political governance are discussed in first 4 chapters. Chapter five refers to the discussion on economic aspects of society and the final chapter discusses on the kinds, methods and various conditions of science [5].

\section{Etymology and Definition of Asabiyya}

'Asabiyyah (of Beduin, pre-Islamic, secular origin: from 'asaba, to bind, to fold, to wind, and 'asâba, the group of male relatives) is one of the most important concepts of the social history of the Arabs and of Islam. Meaning a basic form of social and material human relations, it is a concept which integrates biological, geographical, social, and cultural terms. It is central to Ibn Khaldun's (13321406) theory of civilization (umran), as discussed in his famous Muqaddima [6].

Baali [7] explained it as "...to bind an individual into a group (asabatun, usbatun, or isabatun)." The Encyclopedia of Islam defines 'Așabiyya has originally meaning "spirit of kinship" within the family or tribe, where "...the 'asaba are the male relations in the male line." Thus, asabah refers to the kinsfolk of a person on his father's side. These kinsfolk or relatives are known as "asabah" for they toughen and protect the person and cause him or her to become stronger. Așabiyyah, according to Simon, refers to "... 'the nature of the group' or groupdom." Or in Baali's words, "Așabiyyah signifies" ...to a socio-cultural bond that can be used to measure the strength of social groupings."

The Arabic-English Lexicon gives a long definition of this term [8]. 'Asabiyyah is defined as a quality or characteristic of a person who possesses 'asabiyyu, which are the characteristics of a person in helping his fellows or people against hostility, or being angry and fanatical for the sake of his people or group and acting to defend them. It also refers to the action of a person who invites others to purposely help, join and associate with his group or people against those who are hostile to them whether they are being mistreated or are the offenders.

Lisan al-Arab [9] also gives a definition of "Așabiyyah similar to the above. 'Așabiyyah, according to Lisan al-Arab means a request or invitation from a person to join him or her in helping his or her fellows, whether this group is the transgressor or is being mistreated.

'Așabiyyah in general can be understood as “...man's supporting his people, to whom he belongs, whether they are right or wrong, oppressing or oppressed. The belonging to these people can be due to kith and kin, ethnicity, color, birth 
place, citizenship, school of thought, or a group of people with a common interest." In this sense, 'Așabiyyah is linked to chauvinism, which means "a strong and unreasonable belief that your own country or group is better than others". This kind of spirit arises due to one's feeling of being superior to others, whereas people from other groups are thought to be of lower rank and not as worthy of respect. It can occur in different circumstances, whether in family relationships or matters of descent (which is believed to be the strongest form of 'Așabiyyah), the region where the person or group lives or the group or school of thought to which a group or person belongs. In all these situations, the sense of Așabiyyah implies that someone of their group is superior and looks down on others. Thus, this sense of 'Așabiyyah is condemned by Islam [10].

The term 'Asabiyyah in Ibn Khaldun's theory has appeared in many translations and interpretations by contemporary scholars. In sum, there is no accurate word in the English language for 'Așabiyyah in Ibn Khaldūn's sense [11]. As stated by Arnason and Stauth - "This is one of his most untranslatable terms and Western interpreters have differed widely in their views on its meaning" [12].

Hence, Simon, Baali and Rabi' advise using the term as it is in Arabic without translation, as this practice will preserve its meaning as used by Ibn Khaldūn. However, there are scholars who have attempted to translate the term by such phrases as "group feeling", "esprit de corps", "social solidarity", "group loyalty" [13]. Baali lists the translations of this term in the following: "The term 'așabiyah has been translated as "esprit de corps," "partisanship," "famille," "parti," "tribal consciousness," "blood relationship," "tribal spirit," "tribal loyalty," "vitality," "feeling of unity," "group adhesion," "groupdom," "sense of solidarity," "group mind", "collective consciousness", "group feeling", "feeling of solidarity" and "social solidarity".

De Slane [14] translates it as "espirit de corps", while Rosenthal interprets it as "group feeling", Enan, as "vitality as state dynasty" and Issawi as "social solidarity. However, Lacoste [15] considers that some of these translations, for example, "patriotism", "national awareness and 'national feeling" are incorrect. In his opinion, these suggested translations are incorrect and "anachronistic" and also too general and too modern to be applied in the context of medieval North Africa when "...there were no real nations and tribal structures were dominant" [16]. Hence, some scholars incline to interpret the term from the sociological perspective, whereas others translate it from the political and military perspectives.

Therefore, it is apt to refer directly to Ibn Khaldūn's work to get an accurate sense of the meaning which he intended.

\section{Linking Asabyiah with the History of Bangladesh}

Ibn Khaldun uses the term 'Asabiyyah to describe the bond of cohesion among humans in a group forming community. The bond, 'Asabiyyah, exists at any level of civilization, from nomadic society to states and empires [17]. The concept of "asabiyyah" (Arabic: "tribalism, clanism, communitarism", or in a modern 
context, "nationalism") is one of the best known aspects of the Muqaddimah and Ibn Khaldun's model is an instinctive one, not requiring a conceptual social contract present in classical republicanism. 'Asabiyyah is most strong in the nomadic phase, and decreases as civilization advances. As previous form of this 'Asabiyyah declines, another more compelling 'Asabiyyah may take its place; thus, civilizations rise and fall, and history describes these cycles of 'Asabiyyah (as shown in Figure 1) as they play out [18].

The historical transformation of society and culture in Bengal may be explained very sharply within this theoretical framework (as shown in Figure 2). During the colonial period, the group feeling or solidarity of the people of this delta was merged with the feeling of whole South Asian anti-colonial sentiments. Though it was a move for liberation from colonialism, nationalism was not uncritically singular for Bengali people. But the plurality or diversity of their group feelings became noticeable after getting the independence with certain state boundaries. People of same ethnic origin became the subject of two different types of 'Asabiyyah as because the old form of group feeling did not sustain. Earlier, having only same ethnic or linguistic background was quite enough to

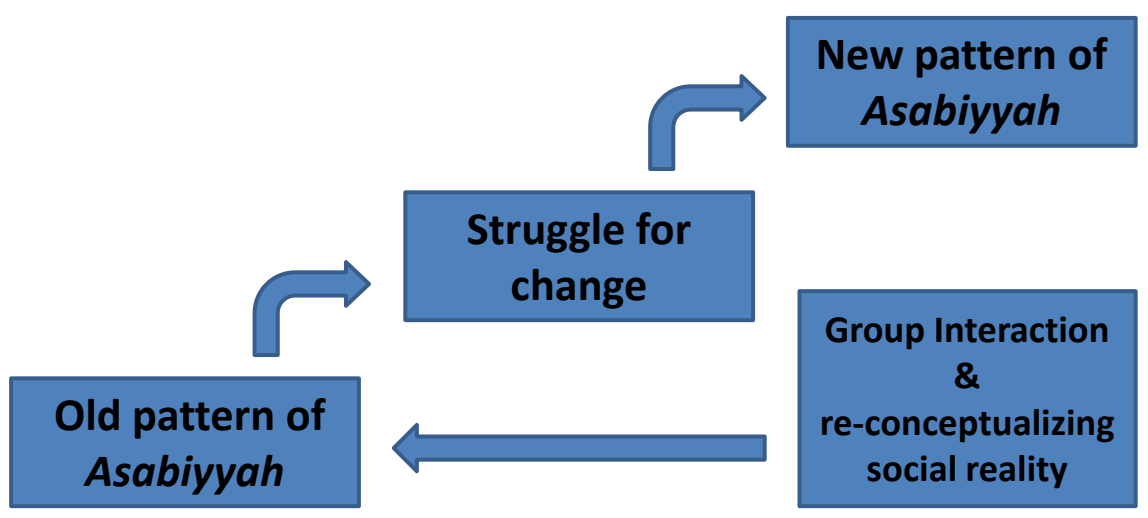

Figure 1. Historical process of formation of 'Asabiyyah.

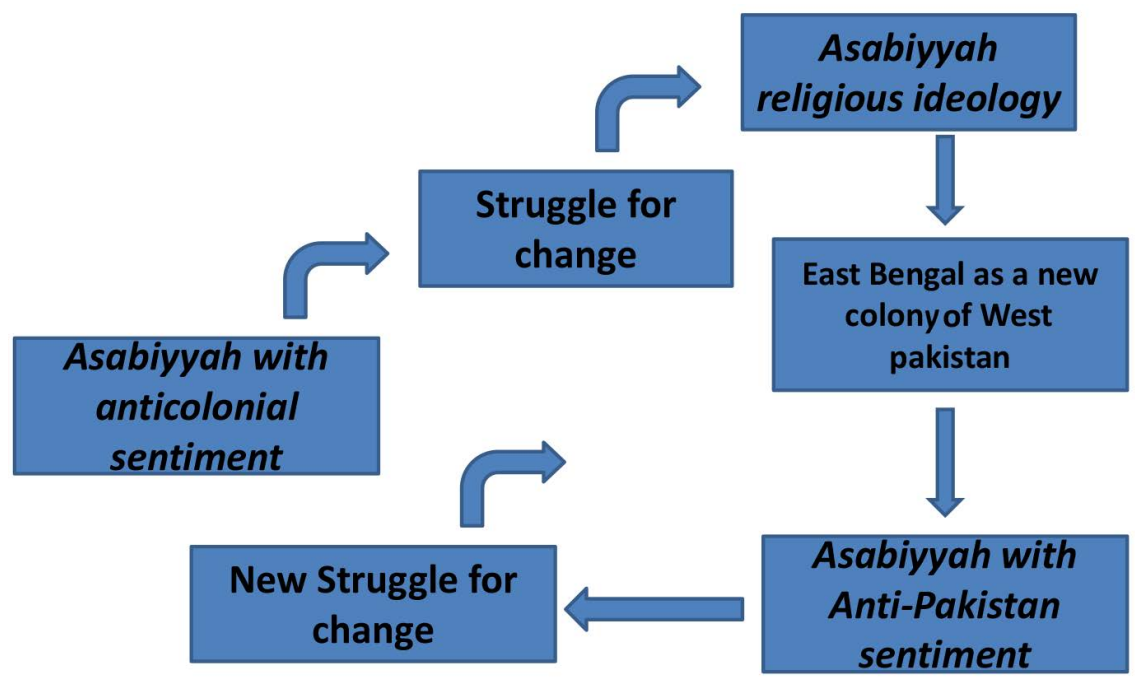

Figure 2. Transformation of 'Asabiyyah in Bangladesh. 
recognize the same type of belongingness within the community whereas later on the religious background and state became very prominent. That is how, the single Bengali community became divided into: Muslim or East-Pakistani or Bangladeshi Bengali and Indian Bengali. In the pages of history or literature, there are many romantic expressions of classical uniqueness of Bengali people but the real truth is that they are now significantly different with different types of 'Asabiyyah (as shown in Figure 3). Here, the West Bengal people had little options to grow new values in their group identity under the greater hegemony of Indianans but the people of East Bengal had much more options to create new history with continuous renewal and reformation of their 'Asabiyyah.

\section{5. 'Asabiyyah and Regional Polity}

Different studies on Ibn Khaldun and 'Asabiyyah—the term, translated into different languages as well. 'Asabiyyah became one of the most daring sociological and anthropological concepts. Today, it is of importance with respect to global issues and intercultural discourses between East and the West and about the 'heritage' of political structures in between societies. Whereas Rosenthal's translation of the Muqadimma reads 'Asabiyyah in mere terms of "group feeling", diverse French and German translations use "esprit de corps", "idea of nationhood", "cohesiveness", or "solidarity" among segmentary tribal or nomadic groups. A complex reading associates 'Asabiyyah not only with group solidarity but also with the striving for sovereignty within and among tribal or family groups. In this sense, 'Asabiyyah also means strong societal effects of solidarity determining the vitality of dynastic or state institutions" [19].

Ibn Khaldun argues that each dynasty has within itself the seeds of its own downfall (as shown in Figure 4). He explains that the ruling houses tend to emerge on the peripheries of great empires and use the unity presented by those areas to their advantage in order to bring about a change in leadership. As the new rulers establish themselves at the center of their empire, they become increasingly lax and more concerned with maintaining their lifestyles. Thus, a new

Bangladesh/East Bengal

Anti-

colonial

Religious

Secularism and Linguistic tradition
West Bengal

Anti-

colonial

Hinduism+

Federalism

Assimilation in 'Hindi' traditions

Figure 3. Comparison between two Bengals historical traditions of 'Asabiyyah. 
dynasty can emerge at the periphery out of their control and effect a change in leadership, beginning the cycle anew [20].

Now, if we look into the global geopolitical situation, it is undoubtedly accepted that the global power structure is in a position of embracing major changes (as shown in Figure 5). Earlier, after the end of "cold war", it was per-

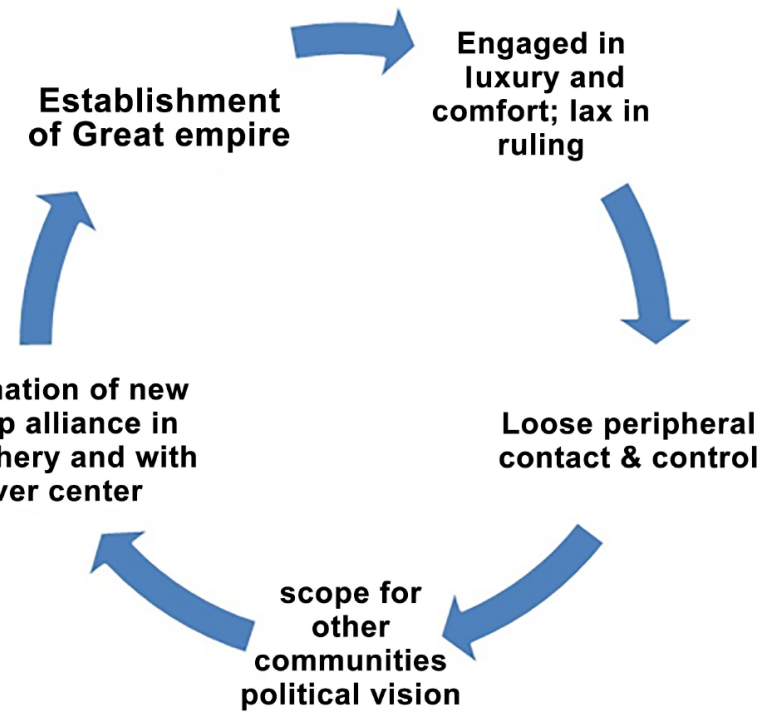

Figure 4. Cycle of power in Khaldun's eye.

\begin{tabular}{l|l|l|l|} 
•Discovering the 'third world' \\
Development projects for the 'third world' as a successful campaign against the growth \\
of socialism
\end{tabular}

Figure 5. 'Asabiyyah in global context. 
ceived that the world has entered into a unipolar system of world order for indefinite period of time led by USA. But recent trends show that the world is moving towards a multi-polar system where no single leader like USA is taken for granted always. Establishment of global or regional banks like NDB (New Development Bank) by BRICS countries, IDB (Inter-American Development Bank) led by Latin American states and AIIB (Asian Infrastructure Investment Bank) led by China signals the economic missions of such multipolar reality of the world order with specific geopolitical interests where all the interests are uniquely common through an anti-American (USA) modality of 'Asabiyyah [21]. USA, sitting in the center of world order is the common opponent of these groups and their regional or global concerted efforts has the potential to create different centers of power rather than being located in the 'periphery' of world order. This is how the monopoly of World Bank and IMF is going to be broken and the same time new polarities are boosting their economies followed by regional geopolitical empowerment. In Europe, European Union (EU) is also playing the same role considering the USA as its major opponent. So, different moves around the globe making things difficult for the 'ruling dynasty' of USA and suppressed leader of old times like Germany or Russia takes the chance of penetrating their ideas in such situation. After being highly disarmed after 2nd world war, Germany has created a position through alternative means in global leadership through EU. On the other hand, in recent days, the 'Siberian tiger' Russia scintillates its sparks through direct military engagement in 'war against IS' in the Middle East, especially in Syria. Role of Bangladesh may be felt very insignificant from the surface against this complex global scenario but the present trends of this emerging state should not be neglected in the context of regional polity. Shifting from a "pro-US" policy to a mixture of "pro-India" and "proEastern" policy are all linked with the greater social and political reality of the world. Geopolitically the position of Bangladesh is very crucial in building the future of both the region: South Asia and South East Asia. SAARC is the organization that had huge scopes for contributing to the development of South Asian societies' development. But, in recent decades it has failed to show any significant success in this regard. Antagonistic relation between two big states-India and Pakistan may be the major reason for this. So, a hungry state for development like Bangladesh can no more wait for any change in Indo-Pak relationship and certainly shifted for alternatives.

For Bangladesh, looking for participation in ASEAN or forming new alliance like BCIM [22] has no alternative to promote its social development through which it can retain its nation or umran. Definitely members of ASEAN or BCIM will get benefits from bank like AIIB since they serve mutual interest.

\section{Asabiyyah and Ethnic Boundaries in Bangladesh}

Yves Lacoste [23] portrays that Khaldun described and explained the social conditions and changes among human beings in the theory of 'Așabiyyah and he further he analyzes the dissimilarities between rural and urban people, referring 
to the Bedouin or nomadic peoples and the sedentary peoples. According to Ibn Khaldūn, the Bedouins or nomadic people are those who have a strong sense of 'Așabiyyah, compared to the sedentary or town people. Bedouin life is simple and seeks only the basic requirements; therefore they are not associated with pleasure, indulgence and luxuries beyond what are necessary. They are also depicted as possessing good characteristics because they are nearer the first and most natural human conditions and their worldly affairs are associated with basic necessities, unlike urban dealings with desires and pleasure which are closer to evil and immorality. Moreover, nomadic people are braver than sedentary people, because the conditions of their life have forced them to set up defenses against danger and not to hope for or depend on others to do this. Danger requires the Bedouin to possess strong 'Așabiyyah whereby they hold to closely-knit groups of common descent, in order to be able to live continuously in the desert. Due to this strong sense and the power and influence of their leaders and shaykhs, they can prevent bad qualities from taking root in the group. They become stronger and more feared by their enemies and obtain mutual support and help from their fellows on the basis that protecting and loving their kin is their priority.

Lacoste also depicts the sense of 'Așabiyyah, from Ibn Khaldunn's view, is as a natural instinct for an individual to protect his blood relatives from being attacked or humiliated by outsiders. To the members of the group, it is shameful if one is incapable of safeguarding one's fellows when they are so treated. Consequently, this feeling leads to close contact and unity within the members of a group. In Ibn Khaldun's words, "Compassion and affection for one's blood relations and relatives exist in human nature as something God put into the hearts of men. It makes for mutual support and aid and increases the fear felt by the enemy".

For Bangladesh, the example of Khaldun's Beduin or Nomadic can be replaced by the "ethnic minorities" or "indigenous people" leaving in the highlands of CHT. Alike Khaldun's interpretation, the intimacy with nature is the main source of the strength of these rural or peripheral groups. All the ethnic groups living in the hills of CHT are unique in their own social, cultural and linguistic traditions. But they are homogeneous in few ways (as shown in Table 1). Firstly, their modes of productions are almost same what they name by "jummo" and secondly they face the similar type of treatment provided by the center of the state mechanism led by the dominant Bengali culture. It has a long

Table 1. Homogeneity and heterogeneity among ethnic groups in CHT.

\begin{tabular}{ll}
\hline \multicolumn{1}{c}{ Homogeneity } & \multicolumn{1}{c}{ Heterogeneity } \\
\hline - Geographical location and habitat : 'pahari' & - Linguistic tradition \\
- Racial category & $\bullet$ Belief system \\
- Social organization & $\bullet$ Political authority \& history \\
- Mode of production: & $\bullet$ Cultural heritage \\
- Horticulture \& livestock & $\bullet$ Level of 'modernization' \\
- Limited hunting \& gathering & \\
\hline
\end{tabular}


historical background of social inequality through cultural devaluation, economic exploitation, political subordination, psychological violation, sexual degradation and military subjugation from the colonial period to till today. Each of around 12 ethnic communities was actually pushed to build a common pattern of 'Asabiyyah in this region for which they were actually not prepared for. Rather they could have their separate kind of group feeling or segregated ones based on the norms and values of their ethnicity. But, common experience of being oppressed created the reality of developing common group solidarity or 'Asabiyyah and they formed a single political platform like JSS ${ }^{1}$ (Jana Shanghati Samity) and later on its military wing Shanti Bahini. For these highlanders, supporting or participating these organizations were an integral part of their self-protection whereas for dominant Bengali, after liberation, it became a matter of pride and prestige to join the regular army. Here, neither the linguistic traditions of hill ethnic communities unique nor they could claim that all the groups have common ancestral linkage. They found the solidarity in their struggle for living and they found the hills, the jungles, the lakes as their source of identity. So, formation of a new type of solidarity or group feeling or 'Asabiyyah was inevitable and thus "Pahari"2 or "Jumma" [24] identity was created (as shown in Figure 6). This was an alliance of all the ethnic groups of $\mathrm{CHT}^{4}$ where they struggle for their rights and came to have a peace treaty with the government in 1997. But the bargaining for rights is still continuing and later on faction among the "jumma" people became very prominent. Still a group namely $\mathrm{UPDF}^{5}$ is working to establish their own form of group feeling that contradicts the political stunt of the CHT majority JSS. Now, after being exposed to mainstream, members of JSS became more urban day by day. On the other hand, operating from underground, UPDF still keeping its rural focus of organizational practice. So, members of UPDF are in direct touch of the harsh reality of jungle which the JSS had in its previous age. In Khaldun's view of 'Asabiyyah, UPDF is

${ }^{1}$ Jana Shanghati Samity (JSS) is the party that led the insurgency in CHT and signed the Peace Accord with the Govt under the leadership of Mr Shantu Larma. In spite of Govt's sincere efforts, the party and its leadership are very vocal and contesting for the full-implementation of the Peace Accord. JSS' political influence prevails mainly in Rangamati and Bandarban districts. Quite often the party demands for the formal ban on UPDF to the Govt describing it as a terrorist group. (For detail, please visit: http://www.globalsecurity.org/military/world/bangladesh/political-parties-cht.htm)

${ }^{2}$ Pahari denotes the people who live in the hills (Pahar) in Bangladesh. This generic identity was initially used by dominant Bengali community to address the 'ethnic minority' people living in the hills in negative sense. Over the period of time, it formulated a discursive identity of all different communities living in the highlands of Bangladesh who face similar kind of socio-political struggle.

3"Jummu" or "Jumia" stands for the people of CHT who share the same mode of agricultural production system called 'jhum' or shifting cultivation. Despite of the ethnic diversity of this hilly area, people discover their commonality or homogeneity through this mode of production and thereafter it became a symbol of their identity.

${ }^{4} \mathrm{CHT}$ stands for Chittagong Hill Tracts specially identified three hilly districts of Bangladesh with ethnic diversity namely Bandarbans, Rangamati and Khagrachari. (For detail, please visit: http://www.mochta.gov.bd/ or, https://en.wikipedia.org/wiki/Chittagong_Hill_Tracts)

${ }^{5}$ United People's Democratic Front (UPDF) is a regional political party based in the Chittagong Hill Tracts of Bangladesh. It was founded on December 26, 1998 seeking to establish full autonomy in the Chittagong Hill Tracts (CHT) through peaceful and democratic means. (For detail, please visit: https://en.wikipedia.org/wiki/United_People\%27s_Democratic_Front) 


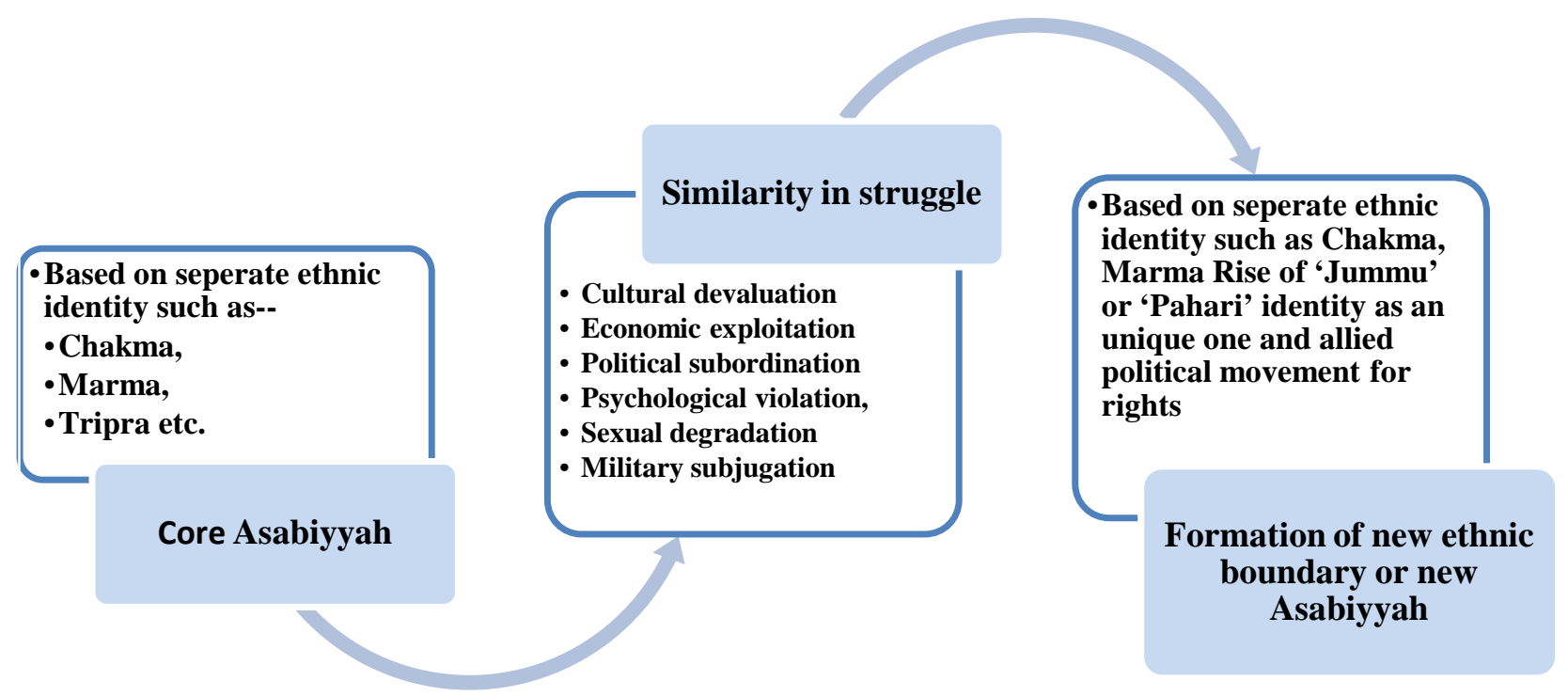

Figure 6. Asabiyyah and ethnic boundaries in Bangladesh.

still in its 'tribal' phase with high degree of command and authority. On the other hand, JSS is moving towards democratic traditions of urban tradition and its form of 'Asabiyyah is not that much cohesive like present UPDF.

\section{Asabiyyah, Umran and Nationalism: Global to Local}

Emergence of nationalism as a political and social concept in systemic version can be traced only 19th century; yet many writers states emergence of the concept to French Revolution of 1789. This is true only in the sense that the revolution brought along Napoleon Bonaparte who institutionalized the concept through conscription, national schools etc. In that sense while emergence of nationalism in the Western world corresponded to end of 18th century, it would be able to access other parts later. Hence, it is wrong to define 'Asabiyyah with nationalism. Nationalism is a modern phenomenon while 'Asabiyyah is claimed to exist in whole periods of history by Ibn Khaldun. Yet one can argue that nationalism is also a kind of solidarity that creates loyalty to state, assistance of same nationalities against others etc. These statements also exist in usage of 'Asabiyyah by Ibn Khaldun.

According to Ali A. Mazrui [25], the word "nationalism" has transcended its etymology. Nationalism is now much wider and more diverse than the unit of the "nation." As we have indicated, it is possible to have transnational nationalism (like that of the Arabs) or sub-national nationalism (like that of the Kurds). The term "nationalism" has come to be associated with certain forms of militant patriotism and with units of allegiance which are more diverse than merely the nation-state. Nationalism may seek to reunite those who have been divided by history and imperialism - such as Somali nationalism and Kurdish nationalism. Nationalism can be either an ideology with specific constituent ideas or a set of sentiments, loyalties and emotional predispositions.

In the Bangladeshi context, nationalism emerged in the course of the devel- 
opment and maturation of the pre and post independent war. But for many European nationalists no distinction was made between loyalty to the state as a system of authority (vertical allegiance) and loyalty to the nation as a fellowship of community (horizontal allegiance). To most nationalists, one's own state or nation was entitled to supreme loyalty. Most recurrently nationalism can be sustained by rivalry for territory and by disputes over borders. Nationalism in both India and Pakistan has been influenced by the dispute over the fate of Kashmir. This is quite apart from the nationalism of the Kashmiri people themselves, in rebellion against forced integration with India.

Nationalism may sometimes be preoccupied with defending culture more broadly. Nationalism can sometimes be sustained by political nostalgia-an idealized memory of the past, with a desire to revive it. The most successful nationalism of nostalgia was the Zionist movement, which did succeed in bringing into being a new Israel (with its citizens now called Israeli's instead of Israelites) [26].

But nationalism can also be sustained by particular negative memories of the past-especially a sense of martyrdom from a specific experience. Armenian nationalism has been partly sustained by the sense of First nationalism movements would be only in second quarter of 19th only as initial movements remaining a kind of elitist movement in the sense that it was tried to introduce through some intellectuals of the age. Moreover, this would not be easy for them because it was not easy to find out a character which could easily surpass others. There should be a solidarity between Arabs in the sense that Ibn Khaldun prefers 'Asabiyyah concept. Yet it seems there was not a kind of it which would surpass other as he claimed "Members of a royal family may be able to found a dynasty that can dispense with group feeling" [27]. Despite of "the fact that the vast majority of newly independent states contained largely Arabic-speaking populations and that they consciously identified themselves as Arab has been a significant feature of twentieth-century Middle Eastern politics" [28]. Arab nationalism has not been accepted as successful at least until today. Moreover, it seems far from being realized than any time before the history since there are nation states and people has begun to identify themselves within states. For example, a Syrian defines himself as Syrian over Arabian. This is also applicable for the case for a Tunisian, Egyptian etc. Even in its heydays Arab nationalism could create an upper identity for people. This can be traced to complex and multicultural, multiethnic, multi-religious characters of the region. "At the end of the nineteenth century large numbers of people living in the Middle East had claims to be called Arabs, for linguistic, cultural and historical reasons. They spoke Arabic and, what was more important, those who could read and write had access to a language that had resisted major dialectization and could be understood from Morocco to the Persian Gulf. They were also heirs to a common culture and a common historical experience based on memories of the Arab and Ottoman Empires. And the vast majority of them who were Muslims possessed not only a common religion but also a set of religious practices, like the pilgrimage, that 
brought significant numbers of them together at the same revered holy sites". However this situation could not bring an upper-identity to Arabs in political sense as Ibn Khaldun claims in the Muqaddimah (as shown in Figure 7. Moreover, the term cannot replace religiosity of society or religion itself could not create a loyalty or strengthen the existing one. "At the end of the 20th century, al-umma in its national connotation is losing vigor while the fundamentalist notion of al-umma is gaining force among Sunnis. The elaboration of Islamist discourses had led some modern Sunni scholars to exclude the non-Sunni communities from al-umma, considering them heretics. Challenging the fundamentalist trend, 'Alawi, Druze and Shi 'ite intellectuals and elites adopted three approaches. The first reiterates the Arabist-Islamist discourse developed at the second half of the 20thcentury, emphasizing the pluralist characteristics of Islam. The second recalls arguments of secular Arabism that detaches religion from nation. The third approach attempts to restore the traditional 'Asabiyyah of their respective religious communities within the political context of modern states" [29].

In comparison of the above discussion, looking back into the history of nationalism in Bengal, it is unquestionable that the spirit of Bengali nationalism is deeply rooted in its linguistic tradition with specific historical evidences that formally kicked off from the language movement of 1952. Most scholars have come to a coconscious that foundation of the nation-state named Bangladesh was not laid by its language movement and the liberation war of 1971 was just a consequence of that spirit. So, formation of this nation what Khaldun mentioned as Umran, can be considered as a very suitable subject of analysis through his theoretical framework. But, alike the complexities of Arab nations or other nations of the world, Bangladesh also had some complex situation that can be discussed from a critical point of view. Apart from the people of Bengali linguistic

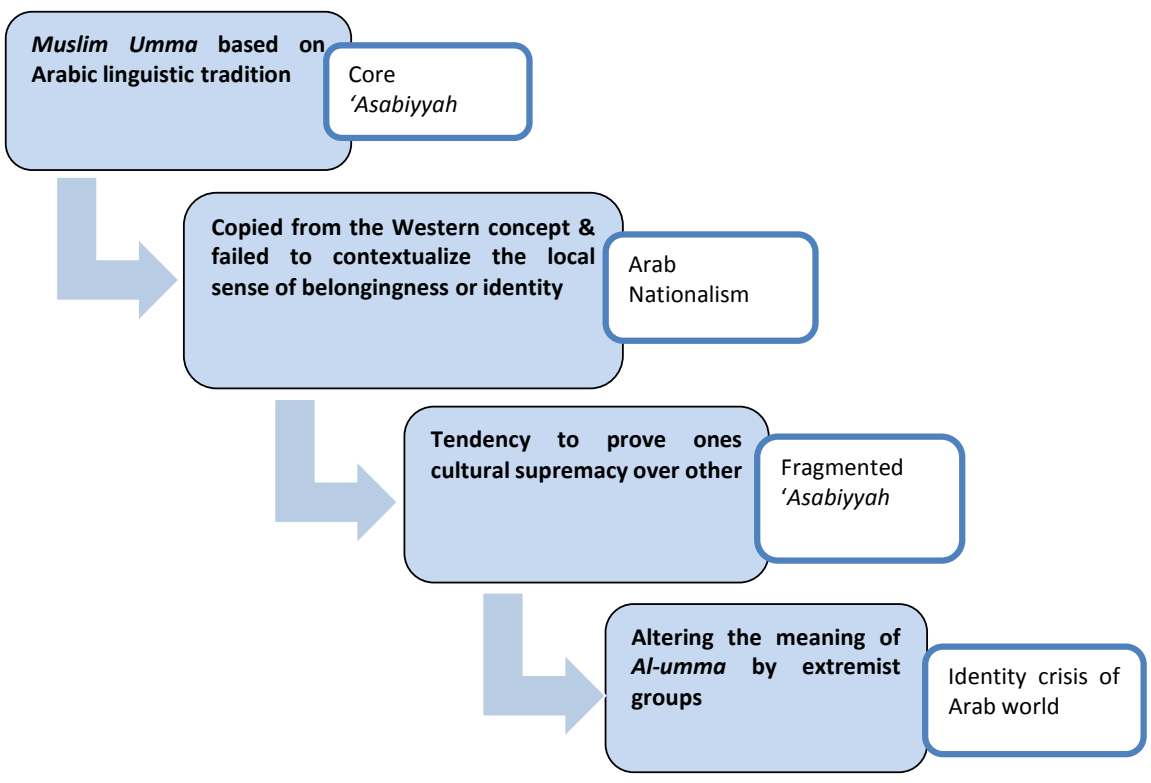

Figure 7. 'Asabiyyah and contemporary Arab World. 
tradition, there were many other ethnic groups who also fought for the liberation of the land. But when "Bengali nationalism" has been essentialized through its popular discourse or through its constitution, other voices of a common 'Asabiyyah discovered themselves as alienated from that spirit. So, the post-independent status of group feeling of solidarity was actually subjected to be challenged by pre-independence kind of solidarity or 'Asabiyyah. During the struggle, alike Khaldun's mentioned "tribal bondage" was very strong but right after the result, championship or credit line became very important. Here the first phase of 'Asabiyyah represents the politics of existence whereas the second phase of 'Asabiyyah represents the politics of identity very sharply. This situation can be explained using the idea of nationalism as 'imagined community' that has been mentioned by Benedict Anderson [30] where the he mentions the idea of nation as an imagined community. According to Anderson, in Europe, nationstates were formed through formation of the minds of people of same linguistic tradition. Printing press played a vital role to shape up the imagination of a common language group and newspapers and novels connected there life events. Here time and space of imaginary and real life situations became quite parallel and the authors or editors had the driving wheel that brought people under the umbrella of similar feelings of imagination. Whereas Khaldun's idea of group solidarity or 'Asabiyyah is a result of true interaction with the natural or material world, the root of nationalism is something different. Kaldun's concept of nation or Umran is as simple as it's "nomadic" societies. But, the idea of nationalism contains natural and man-made phenomena all together with continuous renewal or reformation of its socio-political and socio-economic agendas. The same thing happened for Bangladesh as well. It is such a nation that has the pride of fighting for its liberty and then achieving the victory over its enemy. Same time, critics may have space to raise the question (as shown in Table 2): is this the nation fought for its language and same time it does not recognize the linguistic rights of its ethnic minority? Why is the concept of Bangladeshi Nationalism so controversial to many of its intellectuals? Why is Ethnicity as a unique identity still not recognized by the state policy equally? Why do the leaders or intellectuals are still in debate on identifying CHT people-whether they are "indigenous" or "ethnic minority"? Why cannot the people raise voice against the fallacy of championship disguised in Bengali nationalism?

Table 2. 'Asabiyyah, Umran and Nationalism-The Crisis of Bangladesh.

\begin{tabular}{|c|c|}
\hline Glorious Past & Critical Present \\
\hline $\begin{array}{l}\text { - Heroic liberation war with great } \\
\text { sacrifices of lives } \\
\text { - Victory over its enemy }\end{array}$ & $\begin{array}{l}\text { - Debates on phrasing ethnic identity } \\
\text { - Recognition of ethnic rights } \\
\text { - Appreciation of contribution of different ethnic } \\
\text { communities in the liberation war } \\
\text { - Controversy on Bangladeshi Vs. Bengali. } \\
\text { - Addressing Ethnic identity equally by state in- } \\
\text { cluding its dominant Bengali community }\end{array}$ \\
\hline
\end{tabular}


Answering the above questions may be very sensitive in terms of 'national security' what is actually perceived from a military point of view but the spirit of true 'Asabiyyah says something different. This is simply the fallacy of the ruling 'dynasty' according to Khaldun's thought and the periphery is being subjugated through cohesive power. Thus the erstwhile 'Asabiyyah is broken and the destruction in near future is inevitable if according to the cycle given by Khaldun. The same idea echoes in Yusum M. Sidani's [31] work where he blames the Arab leaders for failing to keep Arab bondage and from Ibn Khaldun's opinion, because of their inability to understand the significance of 'Asabiyyah. But Khalduns framework of leadership also teaches us that we can also resolve the unexpected troubles in future. "Figure 8" shows Ibn Khaldun's perspective of leadership applicable for primordial societies:

In comparison to the above framework, we can refer the modern type of leadership framework as given in "Figure 9". Whereas Khaldun's view of leadership shows us the path of old ways of keeping peace and security within the society with high degree of objectivity, Sidani reveals that the modern or urban reality of leadership having the highest sensitivity to subjectivity towards its environment aligned with the principles of humanism and democracy. The idea of 'Asabiyyah teaches the path how to retain one's group identity and the same time the urban or modern reality is to live with cultural diversities. It is very clear to all in this millennium age that leaving in isolation is the other side of probable extinction. This is the age of alliance and combination of group solidarities. So, the future of Bangladesh is dependent upon the re-association of the

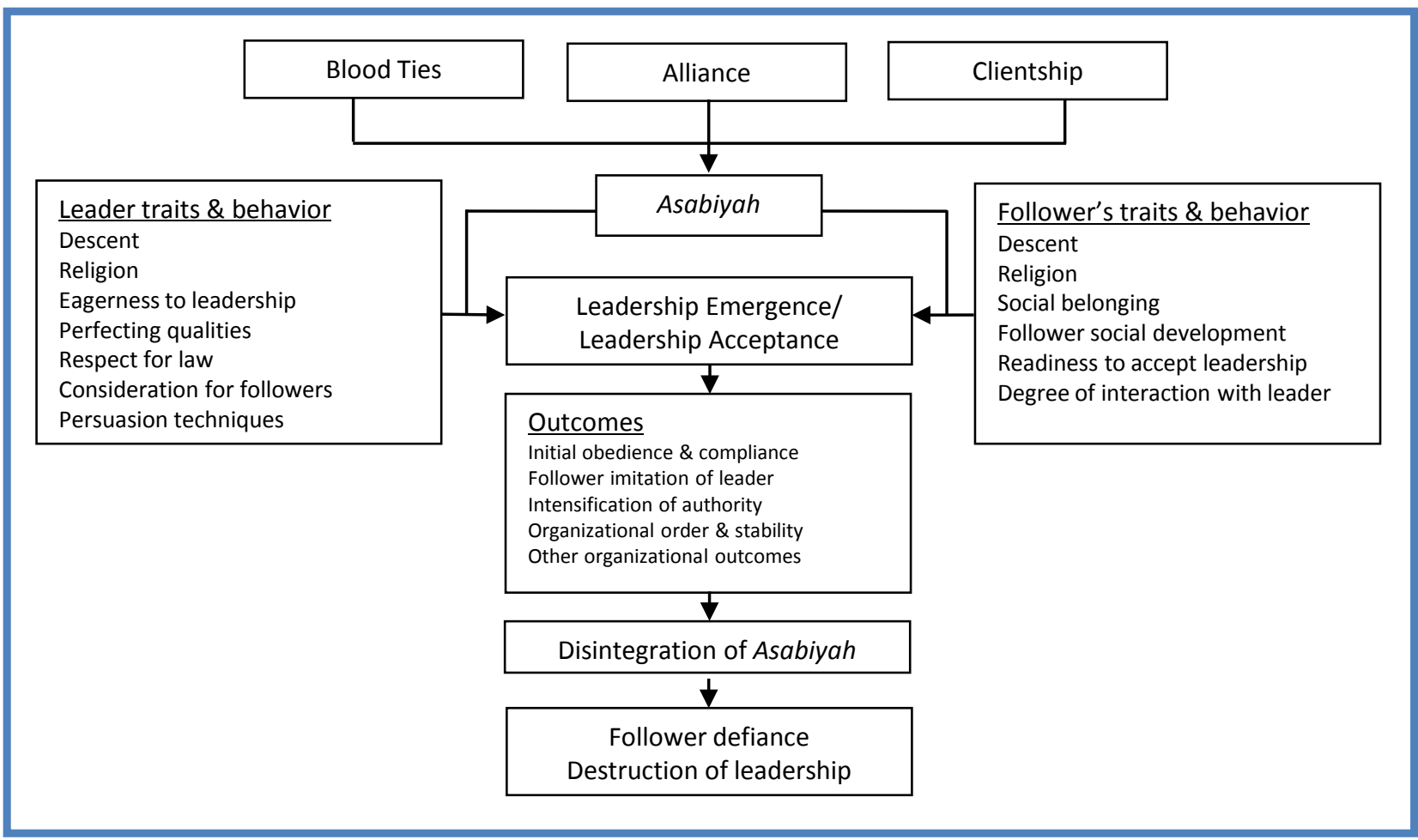

Figure 8. Leadership in primordial societies. 


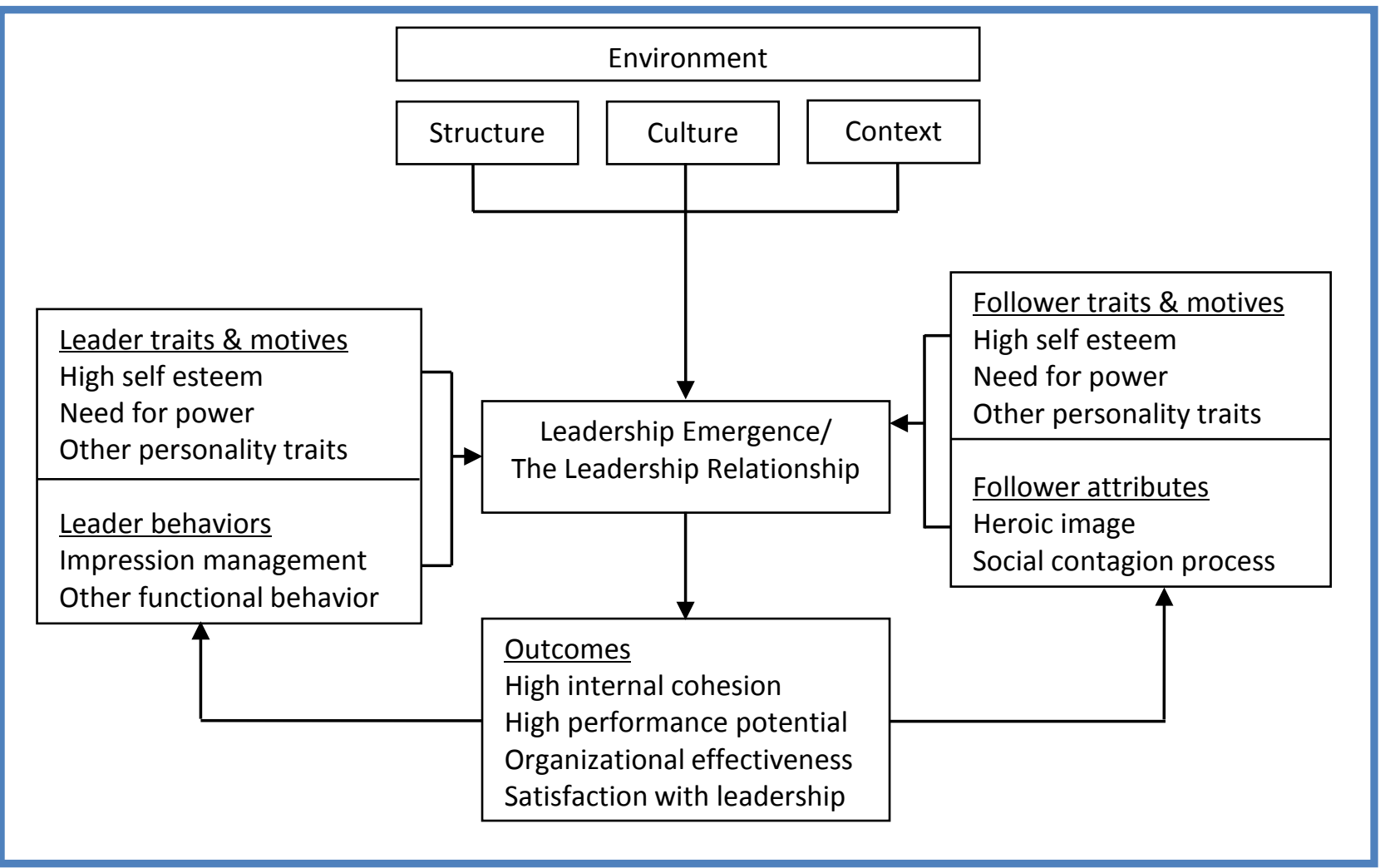

Figure 9. Leadership in modern societies.

broken 'Asabiyyah with its different ethnic groups and this means creating a common form of belongingness. But this is not a very easy task. Yusuf M. Sidani describes that Khaldun explained that there is good 'Asabiyyah and bad 'Asabiyyah. The good 'Asabiyyah refers to the group bond that leads to the fulfillment of common goals while bad 'Asabiyyah is the one that is used to divide and split people purely based on decent or tribal affiliation for unworthy purposes. There are firm political and ideological positions of major political groups in favor or two different types of "nationalistic" manifestos: one in favor of essentializing Benglali Nationalism for all irrespective of identifying ethnic diversities and other one is populist flow of "Anti-Awami" manifestation with mare generalization of its history through "Bangladeshi Nationalism". Khaldun urges against such spirit though the following quotation:

"..... when the religious law ensures group feeling and says: neither your blood relatives nor your children will be of us to you (on the day of resurrection) (such statement) is directed against a group feeling that is used for worthless purposes, ... On the other hand, a group feeling that is working for the truth and for fulfillment of the divine commands is something desirable...."[32].

Among the two conflicting sides, already the first one, the dominant Bengali community, has got its previous glory through $15^{\text {th }}$ amendment [33] of the constitution of Bangladesh but the nation is still not hundred percent confident 
about the common good of all of its citizen as because it illustrates no detail or clear indication of the role of "other cultures" role in the struggle of founding the independent Bangladesh. If we can feel the ethos of Khaldun's spirit of 'Asabiyyah, there must be a common good found through concerted efforts of the leaders from both sides. The study feels that peaceful coexistence of ethnicity and nationalism can be a very effective means in this regard if we really want to glorify our nation or Umran.

\section{Madaniyyah (Civilization) and Self-Ego of Bangladesh}

Arnold Toynbee, the noted historian, recognizing the scope and scale of Ibn Khaldun's work: "undoubtedly the greatest work of its kind that has ever yet been created by any mind in any time or place" [34]. Not only is Ibn Khaldun generally recognized as the "father, or one of the fathers, of modern cultural history and social science" influencing and shaping these disciplines into our time, but his work provides the intellectual point at which other world scholars connect in genuine appreciation. Ibn Khaldun's ideas foreshadow those of our own time. Some of the central formula of the modern age are reflected in Ibn Khaldun's theories: Karl Marx's stages of human history which provide the dynamics for the dialectics of conflict between groups; Max Weber's typology of leadership; Vilfredo Pareto's circulation of elites; and Ernest Gellner's pendulum swing theory of Islam, oscillating from an urban, formal literal tradition to a rural, informal and mystical one.

Emile Durkheim's [35] concept of "mechanical" and "organic solidarity" reflects Ibn Khaldun's notion of 'Asabiyyah or social cohesion. It is 'Asabiyyah that is at the core of the Khaldunian understanding of society and we must return to it. Durkheim, himself one of the founding fathers of modern social science, showed us how the collapse of solidarity led to abnormal behavior in society and then endangers a civilization. He called this anomie. At present, a kind of global anomie is what Muslim society is experiencing as a result of the breakdown of 'Asabiyyah.

There is a fundamental difference however between the modern Western sociologists and Ibn Khaldun. For all his "scientific" objectivity-and for many Muslims it is excessive-Ibn Khaldun still writes as a believer. There is a moral imperative in his interpretation of 'Asabiyyah as the organizing principle of society. Muslims see human beings as having been created to implement the vision of God on earth through their behavior and organization of society.

"Social organization," Ibn Khaldun wrote, "is necessary to the human species. Without it, the existence of human beings would be incomplete. God's desire to settle the world with human beings and to leave them as His representatives on earth would not materialize. This is the meaning of civilization, the object of the science under discussion" [36]. The social order thus reflects the moral order; the former cannot be in a state of collapse without suggesting a moral crisis (as shown in Figure 10).

Though the journey of civilization has been stated by Khaldun from rural to 


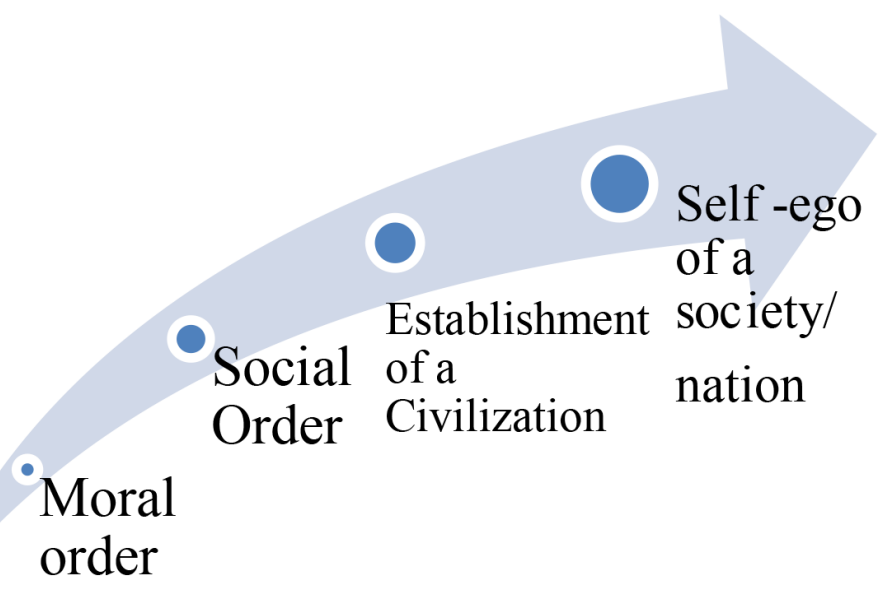

Figure 10. Formation of Self-ego of a Nation.

urban, it was the material part of this interpretation. The other part of this journey obviously non-material and that reflects in the normative theory of civilization by In Khaldun. While addressing human civilization through the eyes of "modern science" the European or western schools has generalized the phenomena though the lens of "evolutionism" and later on this evolutionist school was also criticized by anthropologists since it essentializes the concept of 'progress' which actually contains the idea of "western progress". Though the idea of social evolution was borrowed from Charles Darwin, Herbert Spencer was the theorist of further shaping this theory in social science. Later question was raised like-if the cultural development of a society is highly dependent on its natural environment, then how can be the growth of different cultures or civilization can be measured with some universal phenomena which are not determined locally? This kind of question creates the scope theorists like Ibn Khaldun to understand culture and civilization since he has not identified both material or natural phenomena as well as non-material aspects of society.

For Middle East, the Iranians are the only society that has retained its own modality of social development or transformation against the economic and political challenges by the West. It is not important to discuss whether Iran as a country ethically right or wrong in the global political context. For us, it is important that they have succeeded to build their self-ego both nationally and internationally and recent development in US-Iran relationship is the proof in favor of this argument. There may be many examples of what we call 'extremism' nowadays applicable for Iran which are very popular in Western propaganda but still all other Middle Eastern must adore the social and political achievements of Iran. On the other hand, there are many instances of 'extremism' in other Muslim countries that created no value for them in global platform. In this regard the situation Pakistan or Afghanistan may me mentioned where bad form of 'Asabiyyah created the reason of spreading tension and insecurity at every corner of society. For Bangladesh, recent trends of political leadership may be identified as against such practice though there are clear symptoms of fragmentation 
of its common 'Asabiyyah. When the Prime Minister of Bangladesh addresses the GSP facility in USA for Bangladeshi RMG products as an additional option very boldly, not an essential one, it refers not only a massage from an economic point of view but also has sign of deeper political transformation of the country's image. When Nobel laureate Professor Dr. Amartya Sen [37] distinguishes the concept of development and democracy separately and emphasizes development issues over what we understand by democracy in popular discourse, then it is signal of a kind of advocacy in favor of the present ruling government's approach to the national growth or civilization. In fact, the leadership of Bangladesh is not important for only the people of Bangladesh now but also for the people of its neighboring countries. So, recent identity of Bangldeshi leadership has already been identified by various western agencies and the leader has been identified as very important leader by other global leaders.

Empowerment of the leader empowers his/her followers and the vice versa. Having a very proud history of sacrifice for liberation, the people of Bangladesh are now generating their self-ego not only as a member of the state but also becoming an active part of regional and global history. So, this is the high time for the growth of the civilization Bangladesh towards a new chapter. If we look at the experience of the Arabs or European societies' history very critically, then we may take lessons that neither communalism nor ultra-materialism is acceptable for a better society. Rather, as very moderate normative framework of civilization would be very suitable for this multi-ethnic country with diverse religiosity. This is the land where minds are religious but actions are very secular. This is the condition what A.A. Khan [38] identifies as "congenial social environment" where human mind is shaped like the kind of its land, its river and its nature towards a liberal society. The idea of "secularism" was imported or copied from the west but in practice, AA Khan shows, people of East Bengal enjoyed individual liberty to choose his or her religious belief and there was very limited scopes to be ostracized for the by mainstream society. This is the genuine nature of the people of this land but unfortunately it was derailed by many different political and fundamentalist orientations. But, new struggle has begun and this time people are getting clear message from the state leadership that bad kind of 'Asabiyyah in the name of religion is no more welcomed in this country. So religiosity is not challenged but the 'Asabiyyah is strategically under formation through probable internal and external cooperation. A normative framework like Ibn Khalduns idea of civilization may be very fruitful in this regard. But things should be sensitized to the nature of own culture and society.

\section{Conclusion}

As a country of Muslim majority, Bangladeshi society may find immense potentials in the thoughts of Ibn Khaldun where justice for all religious groups or ethnic communities will be assured. Khaldun's theory of 'Asabiyyah has given answers to several issues highlighted on various indicators ofour solidarity and social cohesion. This paper is done to examine Ibn Khaldun's Muqaddimah espe- 
cially focusing on understanding the meaning of "Asabiyyah concept both from local and global perspectives. But this is a continuous process and the multiplicity of its meaning creates an open space for scholars to set arguable presentations from diverse social and cultural aspects. One must look at the epistemological linkage of the formation of this concept since it is high embedded with the personal experience of Ibn Khaldun by being involved in political intrigue and witnessing the stagnation of the Muslim governments in the 14th century, which made him curious to find the reason behind this situation and which ultimately led him to write the Muqaddimah and propound the theories of Al-Umran and Asabiyyah. Secondly, the theory of Asabiyyah agrees to the concept Ummah and brotherhood based on religion or other key cultural factors. The sense of Asabiyyah, according to this theory, is a natural spirit of social solidarity and cohesiveness which is required for the development of a group or nation. In western phenomena, what we mean by pragmatism is the real approach of "Asabiyyah rather than simply limiting it within "tribalism", "communalism" or "territorialism". A pragmatic approach of dealing and leading society can only make a notion fly from local to global, from national to trans-national spaces of reality with keeping its originality in its core but exploring towards the maximum of modernity.

\section{References}

[1] Al-Azmeh, A. (2005) Ibn Khaldun: An Essay in Reinterpretation. Frank Cass and Company Limited, Digital Printing, New York, 1-8. https://books.google.com.bd/books?id=lP45m-dPUTcC\&printsec=frontcover\&dq=i nau-thor:"Aziz+Al-Azmeh"\&hl=en\&sa=X\&ved=0ahUKEwjW9uWOtJTSAhUYSI8 KHRQNCXoQ6AEIGjAA\#v=onepage\&q\&f=false

[2] Dawood, N.J., Ed. (1969) The Muqaddimah: An Introduction to History. Princeton University Press, Princeton, p. xii-ix.

[3] Rosenthal, F. (2005) The Muqaddimah: An Introduction to History. Princeton University Press, Princeton, p. xxxix.

[4] Rosenthal, F. (2005) The Muqaddimah: An Introduction to History. Princeton University Press, Princeton.

[5] Rosenthal, F. (2005) The Muqaddimah: An Introduction to History. Princeton University Press, Princeton, p. iv-v.

[6] Stauth, G. (2007) Asabiyya. In: Ritzer, G., The Blackwell Encyclopedia of Sociology, Blackwell Pub. Ltd., 180-185.

[7] Baali, F. (1995) Asabiyah. In: Esposito, J.L., The Oxford Encyclopedia of the Modern Islamic World, Volume I, Oxford University Press, New York, Oxford, 140.

[8] Lane, E.W (1968) Arabīc-English Lexicon. Vol. 2, Librairie Du Liban, Lebanon, 2059.

[9] Manzur, M.M. (1997) Lisan al-Arab. Mujallad 1, Dar al-Sadr, Bayrut, Lubnan, 202.

[10] Hawker, S., Ed. (2006) Little Oxford English Dictionary. Oxford University Press, Oxford, 108.

[11] Halim A.A. (2014) Ibn Khaldun's Theory of Asabiyyah and the Concept of Muslim Ummah. Jurnal al-Tamaddun Bil, 9, 33-44.

[12] Arnason, J.P. and Stauth, G. (2004) Civilization and State Formation in the Islamic 
Context: Re-Reading Ibn Khaldun. Thesis Eleven, 33.

http://the.sagepub.com.ezproxyd.bham.ac.uk/content/76/1/29.full.pdf+html

[13] Dhaouadi, M. (1990) IBN Khaldun: The Founding Father of Eastern Sociology. International Sociology, 5, 319-335.

http://iss.sagepub.com/cgi/content/abstract/5/3/319

[14] Bali, F. (1988) Society, State, and Urbanism: Ibn Khaldun's Sociological Thought. State University of New York Press, New York, 43-44.

[15] Lacoste, Y. (1984) Ibn Khaldun: The Birth of History and the Past of the Third World. Verso, University of Michigan.

[16] Issawi, C.P. (1987) An Arab Philosophy of History: Selections from the Prolegomena of Ibn Khaldun of Tunis (1332-1406). Darwin Press, Indiana University, USA.

[17] Mischeli, G.A. (2004) In: Zaunna G.D. and Mischeli G., Strong Family and Low Fertility: A Paradox? Kluer Acdemic Publishers, New York, 92.

[18] Tibi, B. (1997) Arab Nationalism: Between Islam and the Nation-State. Palgrave Macmillan, London. https://doi.org/10.1057/9780230376540

[19] Stauth, G. (2007) Asabiyya. In: Ritzer, G., The Blackwell Encyclopedia of Sociology, Blackwell Pub. Ltd., 180.

[20] Rosenthal, F., (2005) Ch 3:15. The Stages of Dynasties. In: The Muqaddimah: An Introduction to History, Princeton University Press, Princeton, 123-142.

[21] Asia Briefing (2013) 25 October 2013. http://www.asiabriefing.com/news/2013/10/bangladesh-china-india-myanmar-econ omic-corridor-builds-steam/

[22] Bangladesh-China-India-Myanmar Forum for Regional Cooperation (n.d.) Wikipedia.

https://en.wikipedia.org/wiki/Bangladesh\%E2\%80\%93China\%E2\%80\%93India\%E2 \%80\%93Myanmar_Forum_for_Regional_Cooperation

[23] Lacoste, Y. (1984) Ibn Khaldun: The Birth of History and the Past of the Third World. Verso, University of Michigan, 250-263.

[24] Schendel, W.V. and Zurcher, E.J., Eds. (2001) Identity Politics in Central Asia and the Muslim World: 141. I. B. Tauris.

[25] Mazrui, A.A. (2004) Nationalism. In: Goldstone, J.A., Ed., The Encyclopedia of Political Revolutions, Routledge, New York, 364-365.

[26] Mazrui, A.A. (2004) Nationalism, Ethnicity, and Violence. In: Wiredu, K., Ed., $A$ Companion to African Philosophy, Blackwell Publishing Ltd., UK, 472-482

[27] Rosenthal, F. (2005) The Muqaddimah: An Introduction to History. Princeton University Press, Princeton, 125.

[28] Owen, R. (2004) State, Power and Politics in the Making of the Modern Middle East. Routledge, New York, 56-57.

[29] Firro, K.M. (2009) Metamorphosis of the Nation (al-Umma): The Rise of Arabism and Minorities in Syria and Lebanon, 1850-1940. Sussex Academic Press, Sussex.

[30] Anderson, B. (1991) Imagined Communities: Reflections on the Origin and Spread of Nationalism. Verso, London.

[31] Sidani, Y.M. (2008) Ibn Khaldun of North Africa: An AD 1377 Theory of Leadership. Journal of Management History, 14, 73-86.

[32] Ibn Khaldun, A.R. (1974) In: Dawood, N.J., Ed., The Muqaddimah (The Introduction), translated by Franz Rosenthal, Princeton University Press, Princeton, 161.

[33] http://bdlaws.minlaw.gov.bd/print_sections_all.php?id=367 
[34] Toynbee, A. (1972) A Study of History. Oxford University Press, London, 321.

[35] Ritzer, G. (1996) Classical Sociological Theory. McGraw-Hill, California.

[36] Saadeh, W. (1986) History of Arab Thought. Artistic Press, 52.

[37] http://cpd.org.bd/press-reports-amartya-sen-lecture-economic-growth-human-pro gress-cpd-2015/

[38] Khan, A.A. (1996) Discovery of Bangladesh-Explorations into Dynamics of a Hidden Nation. University Press Ltd., Dhaka.

Submit or recommend next manuscript to SCIRP and we will provide best service for you:

Accepting pre-submission inquiries through Email, Facebook, LinkedIn, Twitter, etc. A wide selection of journals (inclusive of 9 subjects, more than 200 journals) Providing 24-hour high-quality service User-friendly online submission system Fair and swift peer-review system Efficient typesetting and proofreading procedure Display of the result of downloads and visits, as well as the number of cited articles Maximum dissemination of your research work

Submit your manuscript at: http://papersubmission.scirp.org/ Or contact jss@scirp.org 